\title{
RADIKALISME POLITIK KELAS MENENGAH MUSLIM INDONESIA PASCA REFORMASI
}

\author{
Wasisto Raharjo Jati \\ Pusat Penelitian Politik-Lembaga Ilmu Pengetahuan Indonesia \\ J1. Jenderal Gatot Subroto 10, Jakarta Selatan, 12710 \\ e-mail: wasisto.raharjo.jati@gmail.com
}

\begin{abstract}
Abstrak: Tulisan ini berupaya mengkaji tentang munculnya kelompok uncivil society di Indonesia. Pengertian uncivil society sendiri dapat diartikan sebagai bentuk kelompok masyarakat sipil yang melakukan aksi-aksi yang bertentangan dengan demokrasi. Problematika mengenai uncivil society tersebut merupakan ekses dari proses transisi dan konsolidasi demokrasi yang tidak sempurna. Hal itulah yang menjadikan proses artikulasi kepentingan kemudian menjadi arena kompetisi satu sama lainnya. Implikasinya kemudian adalah menguatnya perilaku tindak kekerasan yang dialamatkan demi tercapainya suatu kepentingan. Selain itu pula masalah krusial lain yang dihadapi dalam masyarakat sipil adalah fragmentasi ideologi, identitas, maupun juga kepentingan yang berbeda sehingga terkesan pembentukan masyarakat sipil lebih bersifat elitis. Munculnya uncivil society adalah puncak gunung es terhadap proses pendalaman demokrasi yang belum sepenuhnya usai di ranah masyarakat.
\end{abstract}

\begin{abstract}
Political Radicalism of Indonesian Muslim Middle Class in the Reformation Era. This paper attempts to study the emergence of uncivil society groups in Indonesia. The uncivil society itself can be interpreted as a form of civil society groups that perform actions that are contrary to democracy. The problem of the uncivil society is an excess of the transitional process and the imperfect consolidation of democracy. As such, it leads to the articulation process of interest then become the arena of competition with each other. The implication then is the strengthening of the behavior of violence that is addressed for the achievement of an interest. In addition, other crucial problems encountered in civil society are the fragmentation of ideology, identity, as well as different interests so as to impress the formation of civil society more elitist. So the emergence of uncivil society is the tip of the iceberg to the process of deepening democracy that has not been completely over in the realm of society.
\end{abstract}

Kata Kunci: kelas menengah Muslim, demokrasi, uncivil society, kekerasan 


\section{Pendahuluan}

Kelompok masyarakat kelas menengah Muslim di Indonesia merupakan segmen kelompok masyarakat kelas menengah yang memiliki berbagai keunikan tersendiri. Adapun berbagai macam keunikan tersebut dapat dibaca sebagai berikut. Pertama, kelas menengah Muslim Indonesia merupakan kelompok eksklusif dalam kelas menengah Indonesia karena memadukan nilai dan prinsip Islam bersenyawa dengan modernitas. Kedua, kelas menengah Muslim Indonesia senantiasa dikaitkan dengan agenda global yang terjadi dalam lingkup internasional melalui konsep ummah. Ketiga, kelas menengah Muslim Indonesia berpotensi menjadi kekuatan poltik laten mengingat sejarah kontestasi panjang dengan kelompok nasionalis. Keempat, kelompok kelas menengah ini senatiasa ingin menjadi entitas yang diakui sebagai kelompok masyarakat karena selama ini selalu mendapatkan perlakuan stereotipe sebagai kelompok marjinal.

Adanya keempat premis itulah yang kemudian membingkai penting terhadap narasi besar dalam tulisan ini yakni radikalisme kelas menengah Muslim Indonesia pasca reformasi. Pemilihan kata radikalisme sebenarnya merujuk pada kebangkitan gerakan politik sifatnya ekstrem pasca reformasi. Masa itu dipilih karena pasca reformasi sekarang ini, posisi kelas menengah Muslim dalam sistem demokrasi selalu bersikap permisif terhadap kelompok nasionalis dalam konstelasi perpolitikan nasional maupun lokal. Hal itulah yang mengindikasikan bahwa tidak terjadi formasi ulang terhadap aktor politik yang berada di dalam sistem tersebut. Selain itu pula, eksistensi identitas Islam yang diusung oleh kelas menengah Muslim juga semakin terjepit oleh berbagai macam ideologi baru yang masuk dalam masyarakat Indonesia.

Kondisi yang dialami oleh kelas menengah Muslim tersebut turut dipegaruhi oleh perkembangan masyarakat sipil di Indonesia yang cenderung mengalami ambiguitas. Pada satu sisi, masyarakat sipil mengalami liberalisasi politik, namun pada saat bersamaan pula pola terjadinya konflik dan kekerasan di kalangan masyarakat sipil juga meningkat. Hal tersebut dapat terindikasi dari berbagai macam pelaporan berbagai macam LSM maupun NGO yang menaruh perhatian pada pembangunan demokrasi di aras masyarakat.

Adanya serangkaian analisis politik yang telah disampaikan tersebut, radikalisme yang dilakukan oleh kelas menengah Muslim Indonesia menjadi keniscayaan yang tidak terelakkan kembali. Berbagai peristiwa radikalisme yang mengatasnamakan umat Islam sudah tersebar begitu meluas sejak peristiwa 9/11 mulai dari Bom Bali 1 dan 2, Bom Kuningan 1dan 2, Peristiwa Ambon dan Poso, hingga pada NIIS di era sekarang ini. Tulisan sini akan membahas secara lebih lanjut tahapan radikalisme politik kelas menengah Muslim yang terjadi di Indonesia mulai dari munculnya godly nationalism, konteks uncivil society dalam kasus umat Islam merupakan tantangan dalam konsolidasi demokrasi dimana pemberian ruang ekspresi terlalu besar dalam masyarakat justru malah menguatkan adanya semangat eksklusivitas kelompok tertentu terhadap kelompok lainnya, pelaksanaan syariat Islam, hingga masalah khilafah sebagai tujuan utamanya. 


\section{Nasionalisme Ketuhanan dan Munculnya Bibit Radikalisme}

Istilah nasionalisme ketuhanan dicetuskan oleh Jeremy Menchik pada tahun 2014 melalui artikel berjudul Productive Intolerance: Godly Nationalism in Indonesia. ${ }^{1}$ Analisis mengenai nasionalisme ketuhanan dapat disebutkan sebagai bentuk komunitas imaji/ bayangan yang terikat oleh keimanan bersama kepada Tuhan dan dimobilisasi melalui negara yang bekerja sama dengan organisasi keagamaan di level masyarakat. Pengertian nasionalisme ketuhanan berbeda dengan dua diskursus nasionalisme lain yang berkembang dalam studi politik Indonesia, yakni nasionalisme sekuler dan nasionalisme religius. Dalam nasionalisme religius, nasionalisme ditempatkan pada pembentukan ikatan solidaritas dan monoloyalitas pada satu agama saja yang kemudian berujung pada pembentukan negara agama. Sedangkan nasionalisme sekuler lebih menekankan pada terbentuknya ikatan solidaritas dan loyalitas pada terbentuknya negara bangsa berbasis pada aspek kewilayahan. Berbeda dengan dua konsepsi nasionalisme sebelumnya, nasionalisme ketuhanan menekankan pada ikatan loyalitas pada pemeluk salah satu agama yang diakui oleh pemerintah dengan Tuhan sebagai titik sentralnya. Kepercayaan kepada Tuhan menjadi poin penting dalam menjabarkan nasionalisme ketuhanan.

Konteks kemunculan kelas menengah Muslim Indonesia yang sebagian besar didominasi oleh pemahaman being Islam yang berbasiskan pada aspek komodifikasi dan simbolisme Islam menjadi bagian tidak terelakkan dari nasionalisme ketuhanan tersebut. ${ }^{2}$ Inilah sebenarnya pertanyaan penting mengenai relasi kelas menengah dengan nasionalisme ketuhanan tersebut. Konteks islamisasi di kota sebenarnya menjadi poin menarik untuk dikaji bagaimana konteks dakwah Islam di kalangan kelas menengah berlangsung dalam dua level, yakni berbasis syariah dan juga tradisionalitas. ${ }^{3}$ Dua kutub itulah yang kemudian membentuk adanya budaya Islam popular di kalangan kelas menengah Muslim Indonesia yang saling berkontestasi satu sama lain dalam memperebutkan pengaruh ummah. ${ }^{4}$

Dari situlah kemudian Tuhan sebagai civic virtues berkembang sebagai nilai pemaksaan yang dilakukan oleh organisasi masyarakat berbasis keagamaan dan itu "dilegitimasi” secara informal oleh negara. Kondisi itulah yang menjadikan radikalisme tumbuh dalam kelas kelas menengah Muslim di Indonesia. Radikalisme kelas menengah Muslim dapat dianalisis dalam berbagai pola yakni pola ideologi, pola pragmatis, dan juga pola material. Adapun

\footnotetext{
${ }^{1}$ Jeremy Menchik, "Productive Intolerance: Godly Nationalism in Indonesia," dalam Comparative Studies in Society and History 56 (2004).

${ }^{2}$ Rofhani, "Eskpresi dan Representasi Budaya Perempuan Muslim Kelas Menengah di Surabaya," dalam Islamica: Jurnal Studi Keislaman, No. 11 (2017), h. 3-4.

${ }^{3}$ Noorhaidi Hasan, "Islam in Provincial Indonesia: Middle Class, Lifestye, and Democracy," dalam al-Jam'iah: Journal of Islamic Studies, No. 49 (2011), h. 124-125.

${ }^{4}$ Wasisto Raharjo Jati, "Islam Populer sebagai Pencarian Identitas Muslim Kelas Menengah Indonesia" dalam Teosofi: Jurnal Tasawuf dan Pemikiran Islam, No. 5 (2015), h. 140-142.
} 
untuk pola ideologi sendiri lebih bermuatan pada aspek politik yang berujung pada khilâfah. ${ }^{5}$ Pola pragmatis sebenarnya juga memiliki muatan politik yang sifatnya praktis, yakni ingin berupaya menancapkan kekuasaan hegemoni dalam ruang publik masyarakat, peta politik radikalisme kelas menengah Muslim Indonesia dapat dianalisis sebagai berikut: radikalisme berbasis pada ideologi; radikalisme berbasis eksistensi; dan radikalisme berbasis pada materi. Ketiga bentuk radikalisme itulah yang mewarnai wacana mengenai kelas menengah Muslim di Indonesia hari ini. Radikalisme kelas menengah Muslim Indonesia memang terkait dengan upaya membentuk Islamisme, yakni Islam tidak hanya sebagai agama, namun juga sebagai politik. Radikalisme adalah ekpresi politik yang menjadikan Islam sebagai nilai, norma, dan prinsip politik.

Pada pola radikalisme berbasis ideologi, disebutkan bahwa terjadi revivalisme dan penguatan ideologi islamisme yang menguat antar kelas menengah Muslim Indonesia pasca reformasi terutama mengendurnya kekuataan Islam demokrat. ${ }^{6}$ Islamisme tersebut dapat diartikan sebagai bentuk penguatan identitas Islam sebagai entitas tertindas untuk bangkit kembali menuju kejayaan kekhilafahan. Munculnya sentimen islamisme tersebut dapat dipengaruhi oleh berbagai macam faktor dan penyebab, yakni munculnya ideologi salafisme di kalangan kelas menengah Muslim Indonesia pasca reformasi. Indonesia sebenarnya memiliki sejarah panjang terhadap terhadap trend fluktuatif gerakan salafi di Indonesia sejak era mulai Darul Islam (DI) pada tahun 1945 hingga yang mutakhir adalah Laskar Jihad pada medio 2004-2005. ${ }^{7}$ Perkembangan organisasi tersebut mengikuti transformasi struktur dan posisi kelas menengah Indonesia. Sebelumnya kelas menengah Indonesia yang didominasi santri dan kelompok Muslim kota adalah massa ideologis, namun berangsur-angsur kemudian mengecil dalam kelompok kecil masyarakat. Ini karena pertumbuhan kelas menengah Muslim pada masa kekinian justru berkembang dalam kerangka kultur masyarakat mengedepankan adanya simbolisasi daripada substansi. Karena itulah, radikalisme berkembang dalam level usroh, namun memiliki militansi dan ideologi jihad yang kuat dan kental. Karena itulah pengedepanan nilai nilai jihad selalu menjadi inti penting dalam radikalisme kelas menegah berbasis ideologi ini. Pemahaman jihad tersebut lebih mengarahkan pada ekspresi perjuangan politik yang tidak hanya berkembang dalam ranah dunia non politik menjadi politik.

Adapun radikalisme berbasis eksistensi lebih berupa pengedepanan nilai-nilai vigilantilism.

${ }^{5}$ Representasi radikalisme politik Islam pada awal abad ke-20 diperlihatkan oleh Sayyid Quthb (1906-1966). Lihat kajian pemikiran radikal Sayyid Quthb antara lain dalam Mhd. Syahnan, Contemporary Islamic Legal Discourse: A Study of Sayyid Quthb's Fi Zhilal al-Qur'ân (Medan: IAIN Press, 2010) dan "Islam is a System: a Critical Analysis of Sayyid Quthb's Priciple Thought", dalam Analytica Islamica, Vol. 1 Januari-Juni 2002, h. 45-62; dan Muhammad Iqbal dan Amin Husein Nasution, Pemikiran Politik Islam dari Masa Klasik hingga Indonesia Kontemporer (Jakarta: Prenada Media, 2014).

${ }^{6}$ Wasisto Raharjo Jati, Politik Kelas Menengah Muslim Indonesia (Depok: LP3ES, 2017), h. 66. ${ }^{7}$ Noorhaidi Hasan, Laskar Jihad (Ithaca: Cornell University Press, 2006), h. 35-36. 
Adanya pengedepanan nilai-nilai vigilantilism dalam radikalisme kelas menengah Muslim Indonesia lebih ditekankan pada kontestasi wacana ekspresi Islam dalam ruang publik Indonesia yang berusaha mendapatkan pengaruh. Hal itu juga sebenarnya juga berkaitan dengan usaha mencapai simpati dan empati di ruang publik bahwa Islamisme adalah sesuatu yang esensial dalam mayarakat kelas menengah. Adanya penggunaan kekerasan dan intimidasi politik yang dilakukan oleh berbagai kelompok vigilante sebenarnya juga bentuk maskulinitas politik yang berkembang dalam masa pasca reformasi sekarang ini. Pada akhirnya itu kemudian mengarah pada aksi konfrontasi dan konflik politik yang dilakukan suatu kelompok terhadap kelompok. Islam kemudian jadi sumber agitasi penting bagi kelompok kelas menengah Muslim tersebut untuk berkembang menjadi kelompok Muslim paramiliter dalam ranah masyarakat. Namun demikian eksistensi Islam yang dibentuk oleh kelompok vigilante tersebut lebih mengarah pada pembentukan nilai-nilai Islam dalam masyarakat di ruang publik. Ekspresi vigilante memang diakui sebagai aksi responsif dan koersif dilakukan oleh kelompok kecil dalam kelas menengah Muslim Indonesia yang kemudian membesar dalam kegiatan massal. Sebenarnya jika diakui, kelompok vigilante tersebut hanyalah ekspresi ingin mendapatkan rekognisi dari kalangan masyarakat lainnya.

Radikalisme dalam materi lebih dikarenakan adanya masalah ketimpangan ekonomi yang dihadapi oleh kelas menengah Muslim selama ini. Ketimpangan tersebut lebih dikarenakan karena masalah akses dan distribusi ekonomi yang selama ini dihadapi dalam masalah pembangunan. Adanya masalah kontestasi dengan segmen kelas menengah lainnya yang bergerak dalam dunia ekonomi yang formal, sementara bagi kelompok kelas menengah Muslim Indonesia yang selama ini tersisihkan dan lebih banyak bekerja di sektor informal dirasa hal itu tidaklah adil.

Ketiga pola radikalisme yang berkembang dalam kasus kelas menengah Muslim Indonesia kemudian mengerucut pada dua bentuk, yakni pola radikal ekstremis berbasis pada pengembangan ideologi salafi, dan juga pola radikalisme persuasif berbasis pada pengembangan ideologi neo-salafi. Adapun dalam bentuk radikalisme ekstremis berbasis pengembangan ideologi salafi tersebut menitikberatkan pada jihad sebagai esensi utamanya. Adanya transformasi politik kelas menengah Muslim yang berkembang dalam kerangka urban menjadikan ideologi jihad kemudian beradaptasi sedemikian rupa untuk tetap adaptif di kalangan kelas menengah Muslim. Jihad yang semula berdimensi non-politik berkembang menuju gerakan politik. Sedangkan gerakan politik kelas menegah Muslim yang berbasis pada gerakan radikalisme persuasif lebih berperan sebagai kelompok penekan dalam masyarakat Indonesia hari ini.

Berkembangnya ideologi salafi dalam kelompok kelas menengah Muslim di Indonesia sebenarnya menarik untuk dikaji lebih lanjut. Pengajaran salafi yang selama ini dilakukan dan berbasis pada pesantren kemudian secara perlahan membuka pintu ke luar. Selain itu berkembangnya ideologi global jihadis dalam dunia Islam pasca 9/11 bahwa Islam dan Barat adalah musuh bersama dalam selimut. Sementara di satu sisi kelompok kelas menengah 
Muslim di Indonesia adalah entitas yang tumbuh dan berkembang belum lama. Kehadiran mereka belumlah lama semenjak era keterbukaan pasca reformasi. Secara umum kondisi kelas menengah Muslim di Indonesia dihadapkan pada posisi labil karena secara teologis, mereka masih belum memiliki akar kuat karena banyaknya fragmentasi teologi aliran. Selain itu pula, kelas menengah Muslim lebih condong untuk menunjukkan sikap keakuan yang perlu mendapatkan tempat. Ekspresi politik yang condong untuk dipilih adalah bagaimana publik kemudian merasa terpengaruh secara psikis akan hadirnya kelompok kelas menengah tersebut. Dari situlah kemudian, logika uncivilized dikembangkan sebagai mekanisme sahih dalam perebutan ruang kuasa dalam masyarakat.

Ketiga bentuk ekspresi radikalisme pada kelas menengah Muslim Indonesia tersebut kemudian berkembang dalam kerangka uncivil society yang itu kemudian mencerminkan semangat radikalisme dan jihadis yang berkembang di Indonesia. Kelas menengah Muslim Indonesia sebagaimana ekspresi masyarakat sipil pada umumnya pernah mengalami dimensi uncivil society dalam proses transformasi masyarakat Indonesia. Adapun premis penting terbentuknya uncivil society adalah perasaan tertindas sehingga memicu adanya gerakan milisi sipil dalam masyarakat Indonesia. Kelas menengah Muslim sendiri adalah bagian dari minoritas yang kini berusaha menancapkan pengaruhnya kembali sebagai mayoritas dalam sistem masyarakat.

\section{Uncivil Society dalam Masyarakat Sipil Indonesia}

Sebelum membahas lebih lanjut mengenai uncivil society dalam masyarakat sipil, terlebih dahulu perlu dipahami pengertian masyarakat sipil itu sendiri. Konsepsi "masyarakat sipil" sendiri sangatlah multi intepretatif dikarenakan banyak perspektif yang membahasnya. Mulai dari perspektif Liberalisme, Marxisme, hinggga Islamisme. Jika diruntut dari akar kesejarahannya, masyarakat sipil sendiri merupakan padanan dari masyarakat polis di Yunani yang menampilkan adanya semangat partisipatif, egaliter, maupun juga konstruktif dalam membangun demokrasi substansial. Hal itulah yang kemudian menciptakan adanya istilah societas civilis bahwa adanya partisipasi dan aktivisme tersebut salah bentuk "peradaban" masyarakat. Peradaban tersebut kemudian dikembangkan melalui bentuk nilai tatanan sosial, kebersamaan, maupun juga nilai beradab lainnya. ${ }^{8}$

Konteks "peradaban" dalam masyarakat tersebut kemudian berkembang semasa Revolusi Industri, Revolusi Prancis, maupun juga Revolusi Inggris. Saat itulah konteks "peradaban" masyarakat sipil yang semula hanya berupa nilai partisipasi, kini juga berkembang dimensi resistensi. Munculnya tuntutan adanya resistensi tersebut merupakan jawaban atas keinginan untuk membatasi kekuasaan negara yang absolut. Implikasinya kemudian mengarah pada keinginan membentuk adanya representasi politik terhadap negara. Adanya

${ }^{8}$ Agus Sudibyo, "Masyarakat Warga and Problem Keberadaban," dalam Jurnal Ilmu Sosial dan Ilmu Politik, No. 14 (2010), h. 25. 
representasi tersebut kemudian mengindikasikan bahwa masyarakat sipil ingin terlibat dalam proses politik.

Dalam hal ini, perspektif Liberalisme, Marxisme, maupun Tocquevillian mendominasi pemikiran mengenai tumbuh kembangnya masyarakat sipil pasca abad pencerahan. Pemikiran liberalisme sendiri banyak dipengaruhi pemikiran "Pencerahan Skotlandia" (Scottisch enlightment) yang mendasari keinginan tumbuhnya masyarakat sipil sebagai bentuk penjaga etika dan moral. Hal tersebut didasari adanya kebutuhan kapitalisme yang menuntut adanya pembagian kerja dan spesialisasi fungsi. Pemikiran tersebut mendasarkan pada peran masyarakat sipil sebagai pendukung kapitalisme dimana nilai dan etos yang dibangun lebih pada pembangunan kompetisi dan juga representasi. Hal tersebut kemudian diwujudkan dalam bentuk semangat no taxation without representation yang kemudian menginisiasi terbentuknya masyarakat kelas menengah dalam iklim industrialisasi melalui bentuk pengorganisasian sosial macam organisasi buruh, pedagang, maupun borjuasi. ${ }^{9}$

Pemikiran dalam liberalisasi itulah yang kemudian dikritik oleh perspektif Marxian yang melihat masyarakat sipil adalah tempat produksi buruh sehingga merintangi jalan revolusi proletariat. Munculnya masyarakat sipil yang kemudian diikuti dengan adanya gagasan kelas menengah menjadi "aneh" di mata perspektif Marxian karena keduanya merupakan bentuk penciptaan kelas elite dalam masyarakat. Konteks "sipilisasi" dalam masyarakat adalah dengan melakukan revolusi dengan menggerakkan kaum proletariat dan menghilangkan segregasi kelas dalam masyarakat.

Sementara itu, pandangan Neo-Tocquevillian sendiri menganggap bahwa masyarakat sipil muncul sebagai ruang tersendiri dalam negara disamping juga pasar melalui nilai ekonomi (market society) dan juga negara sebagai masyarakat politik (political society). Relasi ketiganya pada dasarnya berimbang dengan prinsip saling mengawasi dengan kompetensi yang saling dimilikinya. Adapun dalam pandangan masyarakat sipil menurut versi Islam adalah konteksnya Masyarakat Madinah pasca hijrah yang menggambarkan masyarakat yang egaliter dan beradab (tamadun). Egaliterianisme tersebut kemudian ditunjukkan dengan adanya semangat toleransi dan tenggang rasa tinggi di tengah masyarakat heterogen.

Uncivil society bisa dikatakan sebagai anti-tesis dari nilai-nilai masyarakat sipil yang telah disebutkan di atas. Dalam pengertian terbatas, kemunculan unicivil society diartikan sebagai anomali dalam masyarakat sipil. Pembangunan justru menciptakan efek destruktif dalam pembentukan nilai-nilai tersebut. Dengan kata lain, uncivil society adalah masyarakat sipil yang tidak sempurna dan dewasa secara utuh karena belum berhasil meredam dampak gejolak sosio politik maupun sosio kultual masyarakat. Munculnya uncivil society dalam transisi demokrasi sendiri merupakan bagian dari proses konsolidasi yang tidak sempurna sehingga memunculkan sikap egoisme dan chauvinisme suatu kelompok terhadap kelompok lainnya.

Pengertian "uncivil society" sendiri tidak bisa dimaknai secara harfiah sebagai "masyarakat

${ }^{9}$ Adam Seligman, Idea of Civil Society (New York: Free Press, 1992), h. 201. 
tidak beradab", "masyarakat non madani", atau masyarakat non sipil". Definisi tersebut lebih mengarah dua pengertian, yaitu kurangnya komitmen dalam menegakkan demokrasi dan kurangnya semangat dalam upaya memberikan upaya penguatan kapasitas masyarakat sebagai kekuatan kelompok politik. Dua pengertian tersebut memberikan definisi bahwa uncivil society adalah kelompok politik sayap kanan atau ekstremis yang anti demokrasi. ${ }^{10}$

Pengertian lain mengenai uncivil society juga dianalisis dengan fokus fenomena pasca rezim komunisme runtuh dan mulai masuknya donor asing terutama dari Barat dalam mempromosikan demokrasi di Eropa Timur. Argumentasi penting dalam fenomena uncivil society di Eropa Timur adalah "clash" pemahaman dan implementasi makna masyarakat sipil untuk diterapkan pada negara-negara yang baru mengalami transisi dari komunisme. Kotkin dalam analisisnya di Jerman Timur, Rumania, dan Rusia melihat bahwa runtuhnya rezim komunis di ketiga negara tersebut bukanlah dorongan dari gerakan populer. Namun lebih dikarenakan pecahnya faksi-faksi pendukung rezim sehingga kemudiaan membentuk sayap politik kanan pada era transisi. Umland kemudian membagi tipologi uncivil society tersebut dalam berbagai kelas seperti halnya kelompok ekstremis Gereja Orthodox, kelompok skin-heads, gerakan Cossack dan kelompok ultra nasionalis.

Kemunculan kelompok uncivil society dalam kasus transisi di Eropa Timur dikarenakan implementasi demokrasi yang berlangsung mendapatkan reaksi dari para elite di era komunis untuk tetap berkuasa. Hal itulah yang kemudian mendorong elite menggunakan saluran afiliasi korporatisme dengan masyarakat untuk meneguhkan posisi politik mereka di pemerintahan demokrasi. Selain itu dari segi masyarakat sendiri, penerapan demokrasi yang setengah hati menimbulkan adanya resistensi dari kelompok masyarakat untuk mendapatkan ruang ekspresi lebih besar. Hasilnya kemudian terciptalah berbagai kelompok kekerasan yang gunanya menciptakan adanya stabilitas. Dalam kasus Pakistan, lebih terlihat bahwa munculnya uncivil society lebih dikarenakan adanya tuntutan demokrasi yang disampaikan oleh masyarakat sipil justru terhenti di kalangan oligarki pemerintahan dan partai. ${ }^{11}$ Justru sebagai aktivis masyarakat sipil tersebut kemudian memilih menjadi partisan dengan mendukung kelompok militer membentuk pemerintahan demokratis. Kasus uncivil society juga bisa disimak dalam kasus masyarakat sipil di India yang justru kian meneguhkan identitasnya sebagai kelompok resisten terhadap negara.

Ketidakpastian yang dialami oleh masyarakat sipil dalam mengambil sikap dalam mendukung berdirinya demokrasi ini memang disebabkan oleh beberapa faktor. Pertama, ruang ekspresi. Dalam era transisi menuju demokrasi yang dibutuhkan adalah ruang konsolidasi dan ruang partisipasi untuk mengartikulasikan kepentingannya. Hal itu terkait

${ }^{10}$ Petr Kopecky, "Civil Society, Uncivil Society and Contentious Politics in Post-Communist Europe," dalam Petr Kopecky dan Cas Mudde (eds.), Civil society, Uncivil Society and Contentious Politics in Post-Communist Europe(London: Routledge, 2005), h. 11.

${ }^{11 Z a i d i ~ A k b a r, ~ " P a k i s t a n: ~ C i v i l ~ a n d ~ U n c i v i l ~ S o c i e t y, " ~ d a l a m ~ E c o n o m i c ~ a n d ~ P o l i t i c a l ~ W e e k l y ~}$ No. 41 (2012), h. 3556-3557. 
dengan posisi masyarakat sipil sebagai pendukung demokrasi. Ruang masyarakat sipil tersebut terafiliasi sekaligus juga terfragmentasi dengan adanya ruang-ruang lain dalam era demokrasi seperti yang terlihat dalam bagan berikut ini. Kasus transisi demokrasi di negara berkembang sendiri banyak diilhami oleh gerakan massa (popular movement) yang kemudian bersatu menjadi sebuah kekuatan kolektif penumbang rezim. Adanya perubahan dari gerakan populer menjadi masyarakat sipil ini menjadi titik krusial karena tidak semua elemen gerakan populer tersebut berubah bentuk menjadi masyarakat sipil. Mayoritas dari aktivis gerakan populer tersebut ingin menjadi aktor kekuasaan dengan demokrasi sebagai komoditas politiknya. Padahal sejatinya dengan merubah karakter gerakan popular menjadi bagian dari masyarakat sipil akan menjaga demokrasi tersebut, seperti yang tergambar dalam bagan di bawah ini.

Tabel 1.

Pembagian "Ruang" dalam Demokrasi ${ }^{12}$

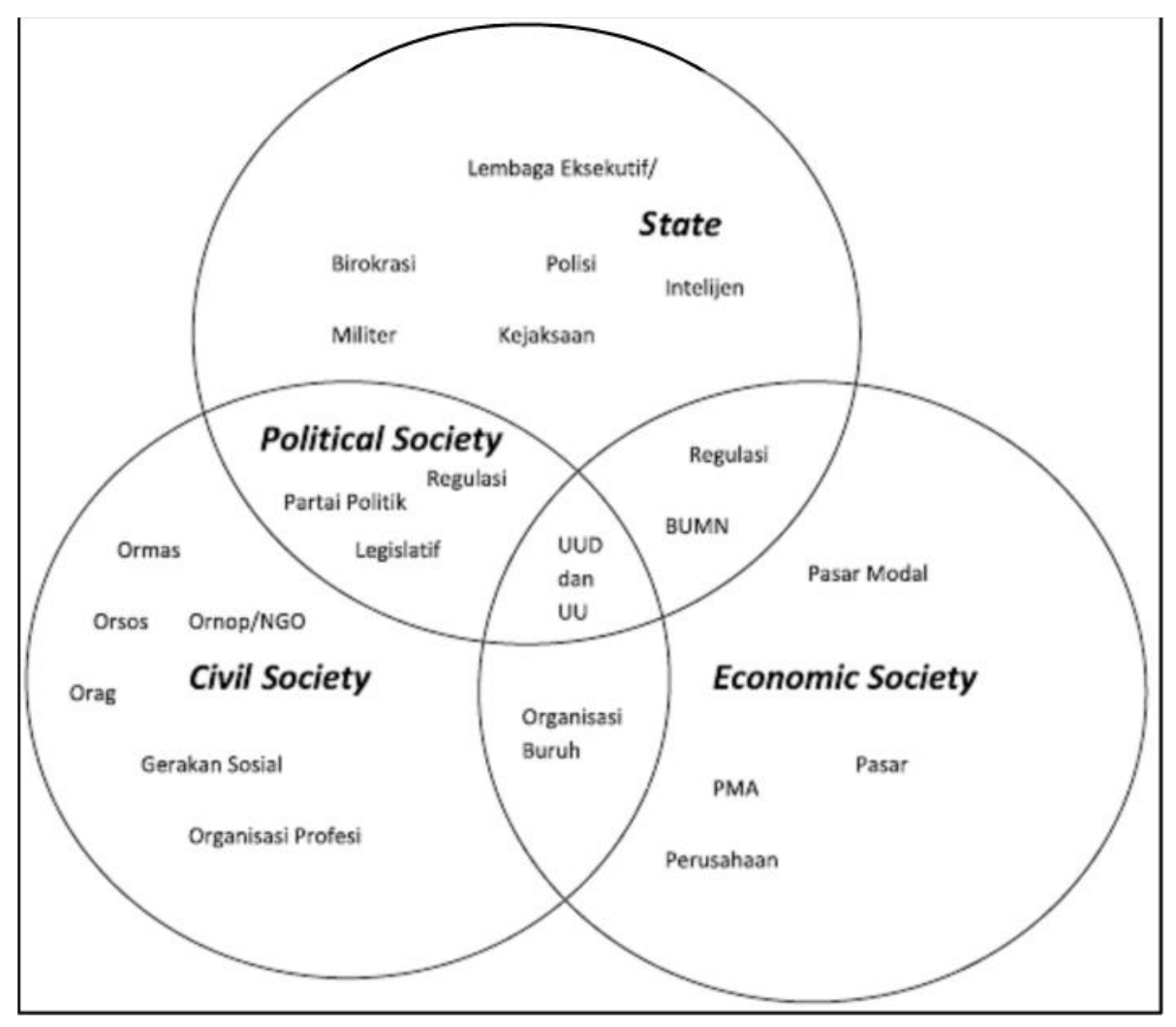

Melalui gambar tersebut di atas, terlihat pola interaksi masyarakat sipil dengan aktor negara maupun aktor pasar. Adapun ruang (sphere) yang saling terkait tersebut berupaya untuk menandakan adanya check and balances masing-masing ruang untuk saling meng-

${ }^{12}$ Stanley Adi Prasetyo, "Mempertanyakan Keberadaan Masyarakat Sipil Indonesia," dalam Fransisca Fitri, Indeks Masyarakat Sipil 2012 (Jakarta: Yappika, 2014), h. xiv. 
awasi dan menjaga. Diskursus mengenai uncivil society dalam kajian masyarakat sipil di Indonesia sendiri belumlah berkembang terlalu banyak. Mayoritas diskursus mengenai masyarakat sipil yang berkembang di Indonesia masih dimaknai sebagai pilar demokrasi secara normatif. Setidaknya hal itu yang bisa dilihat dalam berbagai macam kajian sosial politik kontemporer. Munculnya gagasan "masyarakat sipil" di Indonesia perlu pula melihat konteks regional yang melanda Asia Tenggara dengan munculnya "people power" yang kemudian menelurkan gerakan politik penumbang rezim otoritarian. Belahan dunia lainnya juga menyimak adanya "Solidarnorsch" di Polandia dan juga Peronisme di Amerika Latin yang semuanya itu merupakan kebangkitan dari masyarakat. Pengembangan wacana masyarakat sipil sebagai aktor demokrasi kemudian dimulai dengan wacana pluralisme kekuasaan yang diisi oleh kalangan aktivis yang menuntut adanya kekuasaan negara dibatasi. Dari situlah munculnya masyarakat sipil menjadi prasyarat penting dalam terbentuknya demokrasi yang bisa terelaborasi lebih lanjut dalam tabulasi berikut ini.

Tabel 2.

Komparasi Wacana Perkembangan Demokrasi Indonesia

\begin{tabular}{|c|l|l|l|}
\hline No & $\begin{array}{c}\text { Perspektif } \\
\text { Dasar }\end{array}$ & \multicolumn{1}{|c|}{$\begin{array}{c}\text { Posisi Civil Society terhadap } \\
\text { Demokrasi }\end{array}$} & Kajian Literasi \\
\hline 1 & Tocquevilian & Penyeimbang kekuasaan & A.S Hikam \\
\hline 2 & Lockean & Penjaga moral dan etika, & Mansour Fakih \\
\hline 3 & Marxian & $\begin{array}{l}\text { Bagian dari kapitalisme sekaligus perubahan } \\
\text { rezim }\end{array}$ & $\begin{array}{l}\text { Vedi Hadiz, } \\
\text { Robison }\end{array}$ \\
\hline 4 & Islam & Perwujudan masyarakat yang beradab & Syed Farid Alatas \\
\hline 5 & Governance & Pengawas kekuasaan negara & Pratikno \\
\hline
\end{tabular}

Diolah dari berbagai sumber

Munculnya uncivil society ini memang identik dengan perjalanan transisi demokrasi. Adanya kebutuhan ruang ekspresi, kondisi status quo yang ditinggalkan negara, dan juga instabilitas sosio-politik yang tidak kuat kemudian menciptakan adanya militansi sipil dan juga kelompok kekerasan. Masalah krusial dalam implementasi konsepsi "masyarakat sipil" di negara-negara non-Barat, tentu tidak hanya sekadar masalah nilai dan posisi masyarakat sipil dalam relasi dengan negara. Namun juga saluran representasi masyarakat terhadap arena kekuasaan. Permasalahan yang selama ini agak terlupakan dalam membangun saluran representasi dalam demokrasi sendiri adalah membangun saluran inklusivitas. Selama ini, pembangunan inklusifitas sendiri selalu ditelikung oleh masih mengakarnya jaringan korporatisme negara yang masih kuat. Selain juga karena kemunculan masyarakat sipil yang masih spontan menyebabkan saluran representasi tersebut tidak mengakar kuat. Hal itulah yang menjadikan dominasi korporatisme negara masih kuat sampai sekarang ini. 
Andres Uhlin dalam Oposisi Berserakjuga melihat bahwa dinamika kelompok masyarakat kemudian berkembang menjadi gelombang masa tak beraturan dalam memperjuangkan demokrasi karena ketiadaan konsensus yang ingin dibangun. ${ }^{13}$ Demokrasi yang ingin ditempuh oleh berbagai macam kelompok masyarakat sipil tersebut terfragmentasi dalam berbagai warna ideologis seperti halnya Marxisme, Sosial Demokrat, Liberalisasi, Feminisme, Modernisasi dan Transformasi Islam, serta Konservatisme. Kondisi itulah yang kemudian menimbulkan adanya kompetisi di antara berbagai elemen masyarakat sipil untuk saling mengklaim ideologinya satu sama lain sebagai model yang tepat bagi Indonesia pasca otoritarianisme. Pola ideologi yang ada dalam masyarakat sipil Indonesia sekarang yang cenderung saling sikut-sikutan justru melemahkan pendidikan demokrasi sekarang ini.

Kedua, selain masalah ruang, hal lain yang perlu mendapatkan penekanan adalah ruang partisipasi. Partisipasi menjadi sesuatu yang lumrah dalam demokrasi guna mengekspresikan kepentingan publik. Namun demikian, partisipasi tidaklah serta merta dimaknai secara meluas, akan tetapi justru masih sifatnya elitis. Sikap elitis tersebut perlu dimaknai negara masih melihat konsensus yang dihasilkan oleh masyarakat sipil sendiri masih bersifat formalitas. Di satu sisi, pola korporatisme sisa warisan Orde Baru juga masih ada dan tersisa di struktur masyarakat untuk memelihara loyalitas kepada negara.

Ketiga, bentuk masyarakat sipil. Kasus pembentukan masyarakat sipil di Barat sendiri terbentuk karena adanya sukarela dan kolektivitas. Putnam melihat bahwa pembentukan masyarakat sipil didasari atas kekuatan modal sosial yang kuat sehingga mampu menghasilkan jaringan kuat. Sementara dalam kasus Indonesia, pembentukan masyarakat sipil sendiri lebih banyak diinisiasi oleh donasi donor asing. Pola tersebut kemudian menjadikan besarnya ketergantungan dana terhadap lembaga. Adanya institusionalisasi masyarakat sipil tersebut justru memperlihatkan masyarakat sipil lebih elite dan tidak menyentuh akar permasalahan masyarakat langsung. Pada akhirnya yang terjadi kemudian, masyarakat sipil yang telah terlembaga hanya menjadi pengamat negara namun tidak menguatkan partisipasi warga dari level akar rumput. Konteks tersebut bisa terlihat dari banyaknya aktivis/pegiat LSM di Indonesia banyak terlibat dalam aksi kritik terhadap negara supaya dipandang sebagai organisasi masyarakat sipil berpengaruh dan dilihat negara. Padahal itu sebenarnya tidak perlu dilakukan jika para pegiat LSM tersebut memang secara benar dan nyata mendukung pembangunan demokratisasi dari bawah. Selain itu, masalah krusial lain adalah advokasi agenda setting masyarakat sipil tersebut. Dalam hal ini, advokasi isu yang diambil oleh masyarakat sipil Indonesia lebih bersifat temporer, politis, maupun strategis, namun kurang peka terhadap isu sosial riil terjadi di masyarakat. Adanya advokasi yang dilakukan oleh organ masyarakat sipil sekarang ini lebih bersifat sebagai pemenuhan eksistensi diri dan eksibisi. Implikasinya yang terjadi kemudian adalah tawaran rekomendasi yang disampaikan oleh masyarakat sipil tersebut hanya berisikan diskursus retoris.

\footnotetext{
${ }^{13}$ Andres Uhlin, Oposisi Berserak: Arus Demokratiasi Gelombang Ketiga di Indonesia (Bandung. Mizan, 1998).
} 
Masalah lain yang bisa kemukakan dalam membincangkan masyarakat sipil Indonesia hari ini adalah masalah franchise, misalnya munculnya organisasi masyarakat sipil yang berafiliasi dengan organisasi masyarakat sipil internasional. Pola pembangunan masyarakat sipil Indonesia tidak lebih sekadar kepanjangan jaringan internasional yang memiliki kepentingan atas Indonesia. Ketidakpastian dan ketidakjelasan masyarakat sipil yang mengatasnamakan "masyarakat" ini perlu dipertanyakan kembali posisi dan eksistensinya. Hal ini karena agenda yang diusung oleh jaringan internasional belum tentu sesuai dengan agenda pembangunan masyarakat yang dilaksanakan di Indonesia sekarang ini.

Terhadap ketiga masalah melanda masyarakat sipil Indonesia yang menimbulkan ketidakpastian dalam mendukung demokratisasi tersebut. Kita bisa melihat bahwa terjadi perbedaan dalam pembangunan masyarakat sipil antara model Barat dan model Indonesia. Adanya pandangan optimistik terhadap civil society sebagai prasyarat penting bagi demokrasi mengabaikan fakta tentang pengalaman masyarakat Indonesia pada umumnya. Konsepsi masyarakat sipil belumlah dimengerti secara utuh secara konsep maupun praktik oleh masyarakat Indonesia pada era transisi. Hal itulah yang menjadikan pola pembangunan masyarakat sipil di Indonesia lebih banyak dilakukan dalam aktivisme pergerakan sehingga cenderung memantau kekuasaan saja. Implikasi kemudian pertumbuhan organisasi masyarakat sipil di Indonesia sendiri lebih terpusat di Jakarta ketimbang di daerah. Adapun perkembangan masyarakat sipil non Jakarta lebih fokus pada masalah sosial-kultural saja. Oleh karena itulah perlu ditelaah lebih lanjut mengenai perbedaan pengalaman tersebut.

Pemahaman mengenai civil society di Indonesia mengalami perbedaan dengan di Barat. Dalam kultur negara-negara Barat, konsep masyarakat sipil sendiri diartikan sebagai masyarakat independen, saling bekerja sama, kolektif-rasional, dan bertujuan untuk mengawasi pemerintahan. Titik tekan utama dalam implementasi konsepsi civil society di Indonesia terletak pada gagasan non government (non-pemerintah). Gagasan tersebut tidak serta merta membuat "masyarakat sipil" kemudian mengambil jarak dengan negara secara ekstrem, namun lebih sebagai bentuk pengawalan. Pengalaman demokrasi liberal yang berlaku di Barat menyatakan bahwa posisi masyarakat sipil adalah katalisator adanya moral dan etika. Klaus Eder menyebutkan bahwa masyarakat sipil sendiri adalah penyeimbang terhadap Behemoth dan Leviathan. ${ }^{14}$ Leviathan dalama bahasa Hobbesian sendiri dimaknai sebagai negara "monster" yang tentakelnya menjalar ke segala lini karena tidak ada pengawasan, sedangkan Behemoth diartikan "ketidakkendalian pasar" sehingga justru menimbulkan perilaku destruktif dalam masyarakat. Maka peran masyarakat sipil kemudian diperlukan dalam kapasitasnya sebagai penjaga. Gagasan itulah yang semula diinisasi oleh Adam Ferguson, bahwa masyarakat sipil haruslah otonom agar tidak terintervensi oleh pihak lainnya.

Munculnya perdebatan antara "lembaga swadaya masyarakat" atau "organisasi non-

${ }^{14}$ Klaus Eder, "The Paradox of Political Participation: Theorizing Uncivil Society," dalam Participazione e Conflitto, 7, (2014), h. 563. 
pemerintah" untuk menyebut pergerakan masyarakat sipil di Indonesia menarik untuk dikaji. Munculnya istilah LSM sebenarnya diintrodusir oleh Pemerintah Orde Baru menjelang akhir kejatuhannya untuk memberikan ruang-ruang partisipasi publik selain halnya lembaga korporatisme. Sedangkan istilah NGO sendiri merupakan istilah baru untuk menyebutkan organ masyarakat sipil yang sepenuhnya bebas dari negara. Dari kedua istilah saja terjadi perdebatan mengenai konsepsi "non government" tersebut. Kelompok nasyarakat sipil yang berperspektif swadaya masyarakat akan lebih condong melihat non government tersebut bentuk anti-negara an sich, akan tetapi untuk menunjukkan bahwa dirinya sebagai mitra pemerintah. Sedangkan kelompok masyarakat sipil yang berpandangan dalam perspektif non governmental akan secara ekstrem mengambil posisi sebagai lembaga pemisah negara yang secara benar dan nyata mengambil posisi sebagai bukan bagian pemerintah, atau bahkan terpisah dari negara. Karena itulah, dalam pengambilan posisi, mereka akan mengambil posisi dalam mengkritik kebijakan negara.

Jika menggunakan pendekatan institusionalisme, masalah pelembagaan yang terjadi dalam organisasi masyarakat sipil di Indonesia ada berbagai macam jenis. Mulai dari kurangnya profesionalisme di kalangan ormas, kompetisi di antara berbagai aktor, segmentasi masyarakat sipil berbasiskan ikatan primordial, reposisi masyarakat sipil dalam menentukan arah dan tujuan pasca reformasi, dan perumusan agenda reformasi. Kesemuanya itulah yang kemudian bermuara pada ketidakpastian demokrasi. Manakala pasar berhasil mendefinisikan diri sebagai penyokong demokrasi melalui kapitalisme, seharusnya masyarakat sipil bisa memiliki andil melalui kekuatan modal sosialnya.

Kondisi masyarakat sipil yang tidak terorganisir dan terfragmentasi itulah yang menjadikan dimensi uncivil society sendiri banyak dianalisis dalam perspektif contentious politic. Pengertian tersebut merujuk arena konflik yang melibatkan beberapa individu maupun kolektif dalam mengartikulasikan kepentingan mereka. Pertentangan yang terjadi dalam masyarakat sipil di masa transisi sendiri karena ketiadaan artikulasi kepentingan yang terintegrasi setelah keinginan membentuk pemerintahan demokratis terbentuk. Konflik tersebut yang kemudian berujung pada tumbuhnya sentimen identitas yang kemudian berujung pada aksi kekerasan.

\section{Uncivil Society: Masyarakat Intoleran, Kelompok Kekerasan dan Paramiliter}

Insiasi awal terhadap kajian awal mengenai uncivil society dalam masyarakat sipil Indonesia sendiri dimulai dari karya Verena Beittinger-Lee (2013) dalam (Un) Civil Society and Political Change in Indonesia: A Contested Arena. Ia menjelaskan bahwa munculnya kelompok uncivil society tersebut tidak terlepas dari proses transisi demokrasi yang tidak sempurna di masyarakat. ${ }^{15}$ Ketidaksempurnaan tersebut kemudian dibuktikan dengan

\footnotetext{
${ }^{15}$ Verena Beittinger-Lee, (Un) Civil Society and Political Change in Indonesia: A Contested Arena (London: Routledge, 2013), h. 164-165.
} 
adanya kontestasi vis a vis antara kelompok demokrasi dan kelompok kekerasan dalam memperebutkan pengaruh di masyarakat. Selain itu, alasan lain yang bisa digunakan adalah perebutan berbagai macam sumber ekonomi-politik sehingga mendorong adanya eksklusifitas identitas kelompok. Hadiwinata melihatnya sebagai bentuk dua koin masyarakat sipil yang berbeda dimana pada saat bersamaan mendukung demokrasi, namun di sisi sebaliknya justru menghancurkan demokrasi itu sendiri. ${ }^{16}$ Adanya watak ambigu yang ditampilkan oleh masyarakat sipil Indonesia tersebut lantaran banyaknya ekspresi kepentingan dan aspirasi yang ingin dimunculkan dari akar rumput, namun hal tersebut tidak diikuti dengan pembangunan filter aspirasi yang kuat dari ranah pembuatan kebijakan publik. Kondisi itulah yang kemudian memicu kontestasi kepentingan yang berujung pada aksi konfrontasi fisik. Pada akhirnya hal ini memunculkan mekanisme kekerasan sebagai jalan penting dalam meneruskan aspirasi dari bawah. Pola kekerasan dalam politik menyeruak ketika Orde Baru tumbang dan itu pun diikuti dengan sikap skeptis dan apatis publik terhadap pilhan negosiasi sebagai penengah konflik.

Pola radikalisme yang berkembang dalam masyarakat kelas menengah Muslim Indonesia juga sebenarnya mengalami adanya uncivil society. Hal tersebut terlihat adanya pola indoktrinasi politik Islamisme yang itu kemudian menekankan pada pengedepanan prinsip nilai-nilai anti Barat, anti Kristen, anti demokrasi, maupun juga sikap anti Yahudi. Berbagai sikap "anti” tersebut menunjukkan bahwa kekalahan umat Muslim di Indonesia dalam dunia politik karena kalah bersaing dengan keempat aktor tersebut. Kondisi itulah yang kemudian memicu adanya berbagai macam pergolakan penting dalam mobilisasi massa kelas menengah Muslim Indonesia. Dalam kasus kelas menengah Muslim di Indonesia, mobilisasi Islam kemudian dikaitkan pula dengan terbangunnya berbagai macam identitas pendukung misalnya etnisitas, suku, ras, maupun juga ikatan primordial lainnya. Dengan kata lain, Islam adalah padanan kata yang menarik dalam membangkitkan sentimen primordial tersebut. Radikalisme yang tumbuh dan berkembang dalam kasus kelas menengah Muslim Indonesia tidak mungkin bisa dan berkembang tanpa kebangkitan politik identitas primodial yang mengikutinya. Ini karena pola radikalisme kelas menengah Muslim tidak hadir dalam pola pengajaran teologis panjang berbasis sentimen kesukuan sehingga menimbulkan militansi seperti yang berlaku dalam kasus pengalaman Timur Tengah. Akan tetapi sentimen radikalisme kelas menengah Muslim yang hadir di Indonesia lebih karena perebutan kekuasaan di ruang publik. Kelompok Islam di Indonesia belum sepenuhnya solid sebagai suatu ummah yang itu kasusnya banyak terjadi dalam kasus kelas menengah Muslim hari ini. Itulah yang menjadikan pola radikalisme kelas menengah Muslim Indonesia tidak selalu pada angkat senjata, namun dilakukan melalui berbagai cara.

Dalam perkembangannya istilah uncivil society dalam kasus kelas menengah Muslim di Indonesia kemudian mengalami perkembangan. Radikalisme juga tentunya mengalami

\footnotetext{
${ }^{16}$ Bob Sugeng Hadiwinata, "Uncivil Society and Problematika Penegakan Hukum di Indonesia," dalam Jurnal Hukum Pro Justitia No. 24 (2006), h. 205-206.
} 
kebaruan istilah yang itu tidak hanya sekadar membicarakan mengenai sikap ekstremisme, namun juga dikaitkan dengan berkembangnya perilaku militerisasi dalam tubuh masyarakat sipil secara lebih luas. Pilihan menggunakan mekanisme militerisme tersebut dalam kasus kelas menengah Muslim sebenarnya untuk menunjukkan sikap "kesangaran" dan "kekerasan" yang menunjukkan sikap intimidasi terhadap lawan. Beittenger Lee kemudian mengklasifikan kelompok uncivil society di Indonesia sendiri dalam kelompok militan agama, militan sipil, paramiliter, maupun juga gerakan premanisme. Analisis lainnya yang mengangkat topik tersebut datang dari Nyeman melihat bahwa munculnya uncivil society juga merupakan bentuk resistensi terhadap cara-cara militerisme untuk menyelesaikan masalah dalam demokrasi. Itulah yang menyebabkan penggunaan kekerasan semakin menguat di saat kondisi negara melemah. Di satu sisi, negara ternyata juga membutuhkan kelompok uncivil society dalam menjaga keamanan, ketertiban, dan juga stabilitas masyarakat. Mayoritas kelompok unicivil society ini menjadi backing polisi dalam bekerja sehingga terjadi pola kerja sama antara keduanya.

Perspektif contentious politic menjadi perspektif dominan dalam membaca munculnya uncivil society di Indonesia. Menurut analisis contentious politic, munculnya berbagai macam uncivil society di Indonesia, yakni penolakan terhadap pluralisme politik dalam demokrasi, adanya komersialisasi bisnis keamanan di masyarakat, dan juga ekspresi identitas yang selama ini terkekang dalam masa otoritarian. Karya berjudul Kelompok Kekerasan dan Bos Lokal di Era Reformasi merupakan pintu awal dalam menganalisis uncivil society di Indonesia. Argumentasi penting yang diangkat dalam buku ini adalah kekerasan adalah mekanisme dalam memperebutkan pengaruh kekuasaan di tingkat masyarakat. Demokrasi sendiri kemudian dianggap hanya formalitas bagi menguatnya identitas yang diakomodasi dan diakui negara. Selebihnya kemudian mengenai praktiknya, kekerasan menjadi media utama. Hal itulah yang kemudian menasbihkan adanya kelompok-kelompok kekerasan sebagai penguasa wilayah (war lord). Radikalisme kelas menengah Muslim di Indonesia pada akhirnya kemudian berkembang secara kelompok. Hal itu sebenarnya kemudian menandakan adanya basis massa yang ingin diperlihatkan kepada kelompok lawan. Kondisi tersebut sebenarnya menandakan bahwa kelompok milisi sipil yang berkembang dalam kasus kelas menengah Muslim Indonesia sebenarnya juga saling berkonstestasi satu sama lainnya.

Analisis tersebut kemudian coba dikembangkan oleh Asgart (2006), Salim (2004) dalam melihat kelompok uncivil society tersebut dalam bentuk milisi sipil. Penggunaan istilah milisi sipil tersebut guna mengindetifikasi masih berlakunya cara-cara kekerasan khas militer dalam menyelesaikan persoalan. Masyarakat sipil Indonesia pasca reformasi memang menunjukkan gejala militerisme yang masih terjaga hingga kini. Masih berlakunya caracara militerisme dalam menyelesaikan permasalahan menunjukkan bahwa praktik diplomasi dan negosiasi dalam demokrasi tidak cukup signifikan. Pengertian politik militer dapat diartikan sebagai keterlibatan secara sengaja cara-cara militer dalam proses alokasi dan distribusi 
kekuasaan. ${ }^{17}$ Simbolisasi militer kerap digunakan oleh berbagai kelompok uncivil society dalam mengekspresikan dan mengartikulasikan kepentingannya. Menguatnya militerisme dalam kelompok uncivil society ini tidak terlepas dari warisan mekanisme militer yang belum hilang di masyarakat. Militerisasi masyarakat sipil yang dilakukan oleh Orde Baru melihat bahwa keamanan dan ancaman tersebut bisa jadi datang dari sesama masyarakat. Penciptaan kondisi "siap perang" itulah yang menyebabkan adanya sikap saling waspada satu sama lainnya. Implikasinya kemudian niat dan intensitas untuk melakukan kekerasan terhadap suatu kelompok akan terjadi.

Menguatnya kekerasan yang dilakukan oleh kelompok uncivil society tersebut kemudian berimplikasi banyak terhadap munculnya berbagai macam anarkisme masyarakat di ranah publik. Pemaknaan demokrasi yang masih sebatas proses prosedural menjadikan proses kekerasan menjadi mekanisme utama dalam merengkuh otoritas publik. Hal tersebut tentu saja sudah melenceng dari tujuan awal terbentuknya masyarakat sipil sebagai pengawal demokrasi.

\section{Penutup}

Diperlukan strategi untuk mengatasi meluasnya perkembangan kelompok uncivil society dalam ranah publik, yakni melakukan proses pendalaman demokrasi (deepening democracy). Kelompok kelas menengah Muslim merupakan kelompok masyarakat kelas menengah Muslim yang perlu diarahkan agar tidak berkembang dan membesar sebagai kelompok kelas menengah Muslim Indonesia yang rentan terhadap potensi tersebut. Dikarenakan sifat mereka yang dinamis dan adaptif dalam menerima nilai, norma, dan perilaku dari luar dengan mengatasnamakan Islam.

Saran yang bisa diungkapkan dalam rangka pengembangan kajian akademik mengenai politik kelas menengah ini adalah perlunya studi lanjutan yang mengangkat kasus radikalisme kelas menengah Muslim secara studi kasus. Hal ini menjadi urgen dan signifikan untuk ditindaklanjuti lebih lanjut, karena secara konseptual sebenarnya kajian politik itu menarik dikaji lebih lanjut. Namun dalam dimensi praksis, belum banyak yang mengkaji secara lebih mendalam mengenai sifat dan karakter politik kelas menengah muslim tersebut. Ke depan, perlu ada agenda riset lebih mendalam yang mengkaji hal ini.

\section{Pustaka Acuan}

Adi Prasetyo, Stanley. "Mempertanyakan Keberadaan Masyarakat Sipil Indonesia," dalam Fransisca Fitri, Indeks Masyarakat Sipil 2012. Jakarta: Yappika, 2014.

${ }^{17}$ Evan A. Laksmana, "Dinamika Politik Militer di Indonesia: Kontinuitas dan Perubahan," Beni Sukadis (ed.), Panduan Media and Reformasi Sektor Keamanan (Geneva: IDSPS, 2010), h. 89. 
Akbar, Zaidi. "Pakistan: Civil dan Uncivil Society," dalam Economic and Political Weekly, No. 412012.

Beittinger-Lee, Verena. (Un) Civil Society and Political Change in Indonesia: A Contested Arena. London: Routledge, 2013.

Eder, Klaus. "The Paradox of Political Participation: Theorizing Uncivil Society," dalam Participazione e Conflitto No. 7, 2014.

Fitri, Fransisca. et al. Indeks Masyarakat Sipil 2012: Memasuki Arena Kuasa. Jakarta: Yappika, 2014.

Hadiwinata, Bob Sugeng. "Uncivil Society dan Problematika Penegakan Hukum di Indonesia," dalam Jurnal Hukum Pro Justitia, No. 24, 2006.

Hasan, Noorhaidi. "Islam in Provincial Indonesia: Middle Class, Lifestye, dan Democracy," dalam al-Jami'ah: Journal of Islamic Studies, No. 49, 2011.

Jati, Wasisto Raharjo, "Islam Populer sebagai Pencarian Identitas Muslim Kelas Menengah Indonesia," dalam Teosofi: Jurnal Tasawuf dan Pemikiran Islam, No. 5, 2015.

Jati, Wasisto Raharjo. Politik Kelas Menengah Muslim Indonesia, Depok: LP3ES, 2017.

Kopecky, Petr. "Civil Society, "Uncivil Society and Contentious Politics in Post-Communist Europe," dalam Petr Kopecky dan Cas Mudde (ed.), Civil Society, Uncivil Society and Contentious Politics in Post-Communist Europe. London: Routledge, 2005.

Laksmana, Evan A. "Dinamika Politik Militer di Indonesia: Kontinuitas dan Perubahan," Beni Sukadis (ed.), Panduan Media dan Reformasi Sektor Keamanan. Geneva: IDSPS, 2010.

Menchik, Jeremy, "Nasionalisme Berketuhanan dan Demokrasi Beragama di Indonesia," dalam Sydney Jones. Sisi Gelap Demokrasi. Jakarta: Paramadina, 2015.

Menchik, Jeremy. "Productive Intolerance: Godly Nationalism in Indonesia," dalam Comparative Studies in Society and History, No. 56, 2004.

Puskapol UI. "Indeks Demokrasi Asia: Kasus Indonesia 2014" (presentasi diajukan Departemen Politik FISIP UI, Depok-Jawa Barat, 12 Desember 2014).

Puslitbang Kehidupan Keagamaan Kementerian Agama RI. Laporan Tahunan Kehidupan Beragama 2013. Jakarta: Kementerian Agama, 2014.

Rofhani. "Eskpresi dan Representasi Budaya Perempuan Muslim Kelas Menengah di Surabaya," dalam Islamica: Jurnal Studi Keislaman, No. 11, 2017.

Seligman, Adam. Idea of Civil Society. New York: Free Press, 1992.

Sudibyo, Agus. "Masyarakat Warga dan Problem Keberadaban," dalam Jurnal Ilmu Sosial dan Ilmu Politik No. 14, 2010.

Uhlin, Andres. Oposisi Berserak: Arus Demokratiasi Gelombang Ketiga di Indonesia. Bandung. Mizan, 1998.

Zed, Mestika. Metode Penelitian Kepustakaan. Jakarta: Yayasan Obor, 2008. 